\title{
Creating culture for the new nation South Sulawesi, 1950-1965
}

\author{
Barbara Hatley
}

South Sulawesi might seem at first a less than promising site for exploring Indonesian cultural activities during the 1950s and 1960s. Given the reportedly low level of pre-war education and nationalist organization in the region (Harvey 1977:21) and the fact that it remained part of the Dutch-created Negara Indonesia Timur (NIT, State of Eastern Indonesia) until the end of 1950, one might expect that there was less involvement here in the developing modern, Indonesian national culture than in other parts of Indonesia, less interaction with the major centres of activity in Java. More importantly, during the 1950s Sulawesi was the site of two regional rebellions, the Darul Islam revolt of Kahar Muzzakar in the south, commencing in 1950, and the PERMESTA rebellion of 1957 centred mainly in the north. Problems of political instability, lack of security and social and economic disruption seem likely to have impacted severely on the energy and resources available for cultural activities.

However, precisely because our understanding of cultural life in this period has so far been dominated by attention to the national capital and Java, because it has been assumed that little cultural activity occurred in more distant, contested regions such as Sulawesi, it is important to test such preconceptions, to investigate what was actually happening in these areas. So, although my own previous research on Indonesian literature and performance has been Javabased, here I have taken up the challenge of exploring cultural life in South Sulawesi in the 1950s and early 1960s. Armed with some very useful contacts provided by colleagues, I made brief trips to Makassar in 2008 and 2009, and sought out relevant newspaper holdings in Australian libraries. The picture presented below of is necessarily limited and partial, in keeping with my restricted time and resources. But it reveals a lively cultural scene at odds with previous expectations, and confirms the vital importance of local research for a full understanding of activities across the regions during this time. 
In Makassar I had the great good fortune to be introduced immediately to a man who has contributed invaluably to this research, Mohammad Anis Kaba. In the mid-1950s when he was in his early teens, Pak Anis ${ }^{1}$ became an active, enthusiastic participant in the artistic and cultural life of Makassar. From that time onwards he has documented cultural developments in South Sulawesi, creating an extensive archive of materials - books, programs of plays and art exhibitions, copies of literary bulletins, newspaper cuttings. Several rooms of his house are filled with ceiling-high bookshelves housing boxes of papers; on the walls are displayed paintings, photos of famous national figures, local artists and friends, and posters from old play productions and poetry readings. Anis Kaba and several old friends who called by his home to consult his archive or just to chat, instantly dispelled any misconception that cultural life in South Sulawesi in the 1950s may have been low key or lacking in public attention and support. They talked of play performances and drama festivals, as well as poetry readings, and art exhibitions, and of literary bulletins and newspaper cultural supplements as media for publishing their poems and short stories. Anis produced booklets and clippings illustrating these accounts. Later, consultation of library holdings of newspapers from that period, mainly the Makassar daily newspaper Marhaen, confirmed this picture of busy artistic activity. ${ }^{2}$ In the following pages I trace various elements of this dynamic cultural scene, outlined in roughly chronological order from the late 1940s onwards. Then I attempt to suggest what factors may have produced and sustained it.

\section{CULTURAL ACTIVITIES IN NIT TIMES}

Already in the late 1940s, when Makassar was still capital of the Negara Indonesia Timur (NIT), there is evidence of considerable attention to cultural activity from state authorities, and enthusiastic involvement by artists and intellectuals. A booklet produced in

1 In my personal interactions with Anis Kaba I use the respectful 'Pak Anis' (Pak meaning literally 'Father'); in other contexts I cite his full name. Henceforth, for the purposes of this essay in English, I will use his name without the 'Pak'.

2 I was able to access the holdings, unfortunately very limited, of South Sulawesi newspapers at the Monash University library and the National Library of Australia. At Monash there are issues of Pandji Negara and of Harian Marhaen from 1955-1959 and at the National Library copies of Sulawesi, Madjallah Kebudajaan, 1958-1960. 
1949, entitled Jajasan Pusat Kebudajaan Indonesia Timur (The Foundation for the Cultural Centre of Eastern Indonesia), announces the establishment of this foundation on 5 March 1949. The booklet explains, in Indonesian and Dutch, that the foundation is to be government-subsidized, administered by a group of civil servants and private citizens, and charged with fostering cultural activities in the fields of reading, painting and sculpture, music, film and incidental activities. Its location will be in Fort Rotterdam, where a library, museum, exhibition space, concert hall and meeting rooms are to be established. Outreach activities, such as the provision of reading materials and the holding of literacy courses, will be extended to other areas. The booklet opens with a quote from the speech of President Sukawati, Head of the State of Eastern Indonesia, at the foundation's launching: 'No society will endure unless it is supported by spiritual strength grounded in rich cultural skills.' It goes on to define the foundation's aims as assisting the citizens of Eastern Indonesia to appreciate and promote their own cultures and to learn and absorb from others (Jajasan 1949:7). On the last point we hear the exuberant words of J.E. Tatengkeng (1907-1968), a well-known pre-war poet, at this time Minister of Education in the NIT government:

The Foundation must have connections with Leiden and Amsterdam, with Paris and London, with New York and Sydney, with Cairo and New Delhi. Accept from there what is missing in you and donate part of what is yours. In this way our Foundation will reach its goals, of becoming a centre for the cultivation of established cultures, the building of new cultures and the coming together of the cultures of the world. ${ }^{4}$

While links with Holland clearly were important - the Director of the Stichting voor Culturele Samenwerking (STICUSA, The Dutch Foundation for Cultural Co-operation) discussed in Liesbeth Dolk's paper in this volume, was present at the founding of the foundation and promised extensive support - the notion of Eastern Indonesia as a hub of international cultural connections seems highly fanci-

3 'Tidak ada masjarakat jang kekal, djika ia tidak didukung oleh kekuatan batin, jang timbul dari ketjerdasan kebudajaan jang tinggi' (Jajasan 1949:5).

4 [...] Jajasan ini harus berhubungan dengan Leiden dan Amsterdam, dengan Paris dan London, dengan New York dan Sydney, dengan Cairo dan Delhi. Terimalah disana apa jang kurang padamu dan berikanlah sebagian dari milikmu. Dengan djalan begitu jajasan kita ini akan mentjapai maksudnja mendjadi centrum, mendjadi pusat pemeliharaan kebudajaan lama, mendjadi pusat pembangunan kebudajaaan baru, mendjadi pusat pertemuan kebudajaan dunia (Jajasan 1949:12). 
ful. However, in the field of Indonesian national culture, there is evidence of busy development. Pandji Negara, a weekly newspaper founded in 1948 and produced by the NIT Department of Information, included a cultural segment titled Budaja. A few articles on historical topics and traditional cultures appeared in these pages - relations between the kings of Luwu and the surrounding peoples, Torajan funeral ceremonies, the influence of Bugis-Makassar customs on the Chinese residents of South Sulawesi. But the main emphasis is on national Indonesian cultural forms - poetry and short stories, articles on literature, reviews of recently published Indonesian novels and translated works and theatre performances. ${ }^{5}$

A June 1949 Budaja segment, for example, contains a short report and photo of an allegorical drama, in which characters representing Art and Religion bring together the quarrelling figures of Imagination and Reality. In an introductory speech the play is described as 'a symbol of our growing unity, which is born from the resources of our glorious culture'. ${ }^{6}$ In mid-November 1949, there is a report of the recent staging of another allegorical play, Deru (Thunder), written by A.S. Salman and produced by Panitia Pembangunan Tugu Pahlawan (The Committee for the Construction of a Heroes Monument), where figures such as nationhood, intellectual strength and wealth unite to defend a beleaguered Ibu Pertiwi, goddess of the soil and the Indonesian nation. Previous performances of plays by the same writer are also mentioned, Terus terang (Straightforward) and Terompet (Trumpet), staged respectively by a student group from the town of Bone and a Muslim scouting organization. The Budaja sections of the two following issues contain reviews of plays staged on 19-20 November and 4 December 1949, realistic dramas set in the context of contemporary military struggle and social instability, highlighting themes of moral conflict. The first, Aku gantinja (I replace him) about a spy who infiltrates a guerrilla band, was staged by a group Seni Budaja Makassar (Makassar Arts and Culture). The second, Peperangan antara dua aliran (Battle between two streams), produced by Serikat Islam

5 The Indonesian books reviewed include several novels with Minangkabau settings, republications by the Dutch firm Der Brug of books first published by Balai Pustaka before the war, Achdiat Kartamihardja's Atheis, and an analysis of the Pudjangga Baru literary movement by Takdir Alisjahbana. Two translated works are Don Quixote and Kahil Gibran's The prophet. There is also a review of De Graaf's Dutch language Geschiedenis van Indonesia.

6 '[p] erlambang persatuan kita jang sedang tumbuh, - ialah jang lahir dari sumber-sumber kebudajaan kita jang gilang-gemilang', Pandji Negara, 5-6-1949. The speech-maker is a Professor Dr Hanrath, Head of the Kunstkring Makasar and a member of the board of the Panti Pengetahuan Umum, the Institute of General Knowledge. J.E. Tatengkeng, the NIT Minister of Education, and the head of parliament, Sultan Kaharuddin, are identified as audience members in the photo. I received a copy of this page from Liesbeth Dolk via Jennifer Lindsay: many thanks to both for their assistance. 
Indonesia Afdeling Pandu (the Pandu section of the Muslim organization Sarikat Islam), depicts conflict between two brothers, one who supports the colonial, feudal status quo, the other who champions the cause of the ordinary people. ${ }^{7}$ Besides summarizing the plays, the writers of the reviews also critique aspects of plot, characterization and staging - commenting on instances of psychologically unconvincing acting, poorly conceived scene treatment or inappropriate lighting; praising a skilful, realistic fighting scene. Clearly the Western-derived model of modern drama, employing written scripts and standard stage conventions, was already a familiar one in South Sulawesi at that time. Groups of various backgrounds staged performances. And the role of plays as a medium to comment on social issues and strengthen moral values and promote nationalist ideals was well entrenched.

Of the poems and short stories appearing in Budaja, some address social and political issues, while many focus on themes of love and personal feeling. Literary articles include praise for some local writers, but also criticism of poor language construction and declining poetic skills. Several commentators protest against such negativity, arguing that the enthusiasm and dynamism of young writers needs to be nurtured not discouraged. For the world is on the move and Indonesia is moving too, taking advantage of the opportunities of freedom. One writer praises the achievements of Java-based figures such as Chairil Anwar and Achdiat Kartamihardja, and challenges the writers of Indonesia Timur to match them (Sjarief Saleh 1949). There is a strong sense of involvement in a shared Indonesian endeavour in developing literature and the arts.

\section{CULTURAL LIFE AND POPULAR ENTERTAINMENT IN MAKASSAR}

IN THE 195 OS

After Sulawesi was officially integrated into the Republic of Indonesia in August 1950, the forms and structures of national cultural activity established in the preceding years seem to have expanded and flourished. Several of the numerous daily newspapers published in Makassar maintained weekly cultural segments. ${ }^{8}$ These published fiction and poetry, literary criticism, book reviews and reports on local performances and arts events as well as cultural

7 Pandji Negara 20, 21 November 1949.

8 A list of Makassar-based newspapers obtained from Pak Anis' archives, dating from the mid1950s, contains 10 names: Pedoman Rakjat, Harian Marhaen, Tindjauan, Kurier dari Makassar, Berita Baru, Sulawesi Bergolak, Chia Sing Pao, Daily Telegraph, Kantor Berita Antara and Koresponden PIA. 
developments elsewhere in Indonesia; they also supported play productions and discussions. The one example I have been able to access fairly systematically, Lembaga, the cultural supplement of the daily Marhaen, gives an impression of lively local activities and keen interest in the wider world..$^{9}$ At the same time, newspaper sources convey a sense of busy activity in the field of popular entertainment, broadening the picture gained of more formal cultural structures.

\section{POPULAR PASTIMES}

Popular entertainment in Makassar during the 1950s resembles Marije Plomp's description of the city Medan at this time, albeit on a smaller scale. ${ }^{10}$ Numerous cinemas showed American as well as Malay, Indian, Chinese and Indonesian-made films. In 1955 at least eight cinemas were operating in Makassar, each with three or four sessions daily. A column listing their programs in the newspapers each day sat next to large advertisements of particular shows featuring striking photos - an elegant Grace Kelly in The country girl, Ava Gardner provocatively tempting Humphrey Bogart in The barefoot contessa and embracing Robert Taylor in The knights of the Round Table, a brooding Alan Ladd in The black knight, and a cast of thousands in Arabic-attire in an epic Belal, described as 'the first and biggest history of Islam'. ${ }^{11}$ Hollywood films predominated, promoted with much fanfare (for instance, full-page newspaper advertisements for a six-day 'Universal-International' film festival at the Empress cinema, including The Glenn Miller story, Magnificent obsession, So this is Paris and Creature of the Black Lagoon), along with some Indian films and a few Malay productions. By the end of the decade offerings appear more varied; while American films are still the most numerous, there are occasional Chinese, Japanese and Filipino movies as well as Indonesian-made classics such as Usmar Ismail's Tiga dara, Terang di bulan, Terang di kali and Kunanti di Djokja.

The programs of the state-owned radio station, Radio Republik Indonesia, as published in the daily papers, demonstrate an eclectic variety. Fridays are marked by early morning Koranic chanting, the midday sermon from the main Makassar mosque broadcast live,

9 The segment is subtitled 'Notes sastera dan budaya' (Notes on literature and culture). Use of the English word 'notes' may suggest a conscious cosmopolitanism.

10 Plomp reports in her contribution to this volume that Medan had sixteen movie theatres at this time, while many bands and singers making broadcasts on Medan radio enjoyed popularity also in Malaya and appeared in Malay movies.

11 Harian Marhaen, 8-12-1955. 
and Arabian style gambus or kasidah music. ${ }^{12}$ A sample Saturday program in early 1955 includes Chinese, Moluccan and Javanese keroncong music, the intriguingly-titled 'Juke box Saturday night' and a direct broadcast of entertainment from the Panti Hiburan theatre building, ${ }^{13}$ a Sunday program from 1956 mentions a Catholic talk, a Protestant church service, sung devotions by a Pentecostal singing group and seriosa and keroncong music. ${ }^{14}$ Musical programs formed the core of radio offerings, presented by the resident orchestra, Orkes Radio Makassar, and by local groups such as Pemuda Maluku (Moluccan Youth) and the Badjiminasa orchestra, specialists in modern Makassarese song. ${ }^{15}$ Competitions to select star radio performers, held each year to mark Radio Day on 11 September, with Makassar region winners potentially going on to compete at the national level, were an important focus of attention. ${ }^{16}$

Visits by touring artists from Jakarta and overseas were another way in which popular entertainment in Makassar interacted with a wider world. The Pekan Raya Ekonomi II, the Second Grand Economics Fair, in August 1956, for example, involved 70 participants in a show touring from Jakarta described (in English) as 'The Great Travelling Carnival Show', and 36 acrobats from Beijing, sponsored in part by the local and national branches of the Chinese-Indonesian friendship association. Crowds were estimated to number 60,00070,000 per night. ${ }^{17}$ Along with popular entertainment, news stories also could draw Makassar residents into imaginative involvement with the wider world. The ill-fated love affair between the British royal family's Princess Margaret and divorced commoner Group Captain Townsend is frequently mentioned, for example, in the newspapers of 1955. Accounts of actions by gerombolan (Darul Islam rebels), including the killing of 100 villagers and disruption to the holding of elections, share newspaper space with updates on the romance and an analysis prompted by the affair of the disruptive role of romantic love through the ages. ${ }^{18}$ Immediate hardship and suffering apparently did not impede interest in and empathy with distant lives. ${ }^{19}$

12 Harian Marhaen, 2-12-1955, 28-12-1955.

13 Harian Marhaen, 5-1-1955.

14 Harian Marhaen, 4-8-1956.

15 Harian Marhaen, 1-12-1955, 17-12-1955, 28-12-1955.

16 Harian Marhaen, 19-7-1955, 15-9-1956.

17 Harian Marhaen, 10-8-1955, 13-8-1955, 29-8-1956.

18 Harian Marhaen, 10-11-1955.

19 Some suggest that the effect is just the opposite, that hardship increases the appeal of pleasurable distractions. See Marije Plomp's observation in her essay in this volume on similarities between the thriving popular culture of Medan in tough economic times during the 1950 s and the popularity of cabarets, films and soccer games in the Netherlands during World War II. 
The year 1955, the year of Indonesia's first elections, was a time of busy growth in arts structures and activities in Makassar. The daily Marhaen, connected with the PNI nationalist party, began publishing in 1955 a cultural segment Lembaga, which focuses on Indonesian culture as shared, national cultural expression, informed by and open to international developments. The 19 October issue presents a report of the painter Affandi's recent successful international tour of Europe, analysing the strengths of his work and highlighting Affandi's observation that he didn't meet many great European artists, while Indonesia has ten artists of international standing. ${ }^{20}$ The next edition contains a positive discussion of the musical form keroncong, as national music that can be enjoyed by Indonesians of all regions, now free of its past shady associations and appearing in respectable contexts such as radio competitions. ${ }^{21}$ The following week a writer warns of the dangers of intimate, Western-style dancing for young people. While not advocating a ban on such dancing, not wanting to keep young people old-fashioned but rather to embrace the modern world, he sees the need for some control. ${ }^{22}$ Elsewhere in the same edition appear reports of the establishment in Jakarta of a committee to study Malay-Polynesian languages, of a coming play performance in the city of Medan and the award of the Nobel Prize for literature to Icelandic writer Halldor Killjan Laxness. ${ }^{23}$

The Lembaga of 10 November 1955 turns attention to a key local event, the Festival Senidrama Indonesia I, the first Indonesian drama festival. Commencing that day and continuing until the first week in December, the event is described as the first drama festival in the history of Indonesian theatre. After suggesting that Makassar cultural leaders can be justly proud of this achievement, the writer criticizes government bodies and private donors for failing to properly support the event. He/she then goes on to explain its aims to increase public interest in theatre as a very important medium combining other art forms, such as literature, music and visual arts, to raise the standards of performance, and to overcome the previously poor social reputation of theatre and its performers. ${ }^{24}$

20 There are also some poems on battle themes commemorating Armed Forces Day and a short story Sebelum bulan baru datang (Before the new moon comes) by A. Rosady Sany (Lembaga 1-33 in Harian Marhaen, 19-10-1955).

21 Lembaga 1-34 in Harian Marhaen, 26-10-1955.

22 Lembaga 1-35 in Harian Marhaen, 3-11-1955.

23 The report states that the performing group Keluarga Tunas Medan is to stage the play Diriku tak ada.

24 Lembaga 1-36 in Harian Marhaen, 10-11-1955. 
Other sources confirm the prominence of the festival in the cultural life of the time. Whatever the significance of the reported lack of practical assistance from government bodies, verbal expressions of support from official figures were expansive. The acting governor of South Sulawesi, Andi Boerhaddin, in his opening speech for the festival describes the event as an expression of the progress of the Indonesian people, in not only achieving political independence but also reviving the noble spirit of Indonesian culture, which had been obscured by the influence of colonialism. He also strongly emphasizes the educative role of drama. The Commander of the Armed Forces, J.F. Warouw, likewise speaks of restoring the beauty and grandeur of Indonesian culture, and expresses his great pride in the holding of the festival, which provides evidence to those outside Sulawesi of the security and advancement of the region. ${ }^{25}$ Two of the organizers, Andi Sapada Mappangile, head of the festival committee, and Andi Baso Amier, the publicity officer ${ }^{26}$ cite the aims of the festival as developing and raising the standard of drama, as an important part of national culture, and providing an attraction for the public, described as thirsty and lonely ('haus dan sepi'), because of the conditions around them. ${ }^{27}$ Eight groups participated in the festival. These included a group called Tifa (a term for a small drum) that represented the cultural supplement of the newspaper Pedoman Rakjat; Lembaga Seni Film dan Drama (LESFIRA, Institute of Film and Dramatic Art) a Makassar-based film and drama organization; and Peladjar Seni Drama (PELSEDRA, Drama Students' Group), a group of drama students from the town of Pare-Pare. ${ }^{28}$ The performances are listed as three domestic dramas, three plays with a nationalistic background and one adaptation of a traditional legend about love and heroism. ${ }^{29}$ All are described as realistic in style (Fahmi Syariff, n.d.: 32).

25 These statements appear in a commemorative booklet for the festival, a photocopied version of which I obtained from Anis Kaba.

26 Andi Sapada Mappangile was a prominent cultural figure, the husband of Ibu Andi Nurhani Sapada, the famous dance choreographer; both are discussed below. Andi Nurhani herself also participated in the organization of the drama festival. Andi Baso Amier was a prolific and acclaimed writer and cultural organizer.

27 The comments by Andi Sapada and Andi Baso Amier are quoted in Fahmi Syariff (n.d.:31). The comment on difficult social conditions for the people of Makassar seems likely to refer to the disruption caused by the Darul Islam rebellion, among other hardships. Such issues generally find little mention in the arts and literature sections of newspapers and reports of cultural activities, although they are reported regularly in other pages of the newspapers.

28 The other groups mentioned are Ikatan Penggemar Seni Indonesia (IPSI, League of Indonesian Art Lovers), Tjenderawasih, Pertip, H.K.I. Sehati and Mekar. Unfortunately I have not been able to find out the full names of the organizations Pertip and HKI Sehati.

29 One play is missing from the list as there is no documentation available. 
Other cultural activities taking place in Makassar in 1955 included a painting exhibition and a music festival or Pesta SeniSuara held on 13-14 December, shortly after the Drama Festival reviewed above. Both were organized by the Makassar branch of Lembaga Kebudajaan Rakjat (LEKRA, Institute of People's Culture), which had been established in April 1955. ${ }^{30}$ An article in Lembaga in late December comments on the lively state of the arts scene and the growing confidence of artists. The writer then discusses the music festival, praising its focus on local popular songs and their composers, as an expression of the culture of ordinary people. ${ }^{31}$ Given the bitter ideological clashes in later years between LEKRA and other cultural groups, the positive reports of the art exhibition and music festival in newspapers of this time are noteworthy. Government officials were also supportive. J.E. Tatengkeng, by then Head of the Department of Culture of the Province of Sulawesi, spoke at the art exhibition, expressing his appreciation and looking forward to future collaboration: the Acting Governor of Sulawesi, the Mayor of Makassar and the Department of Culture contributed to the prizes for the competitions at the music festival. ${ }^{32}$

Subsequent years saw ongoing activities in national literary, performing and visual arts. The literary supplements of the newspapers continued to publish poetry and short stories along with discussions, sometimes heated, of issues such as a perceived crisis in literature and problems in the teaching of literature in schools ${ }^{33}$ or the function of the artist in society. ${ }^{34} \mathrm{~A}$ second drama festival was held in June 1957 and a theatre conference in November 1958: ${ }^{35}$ a theatre academy, Lembaga Akademi Seni Drama Indonesia (LASDI, Institute for the Indonesian Academy of Drama), was established in March 1959. Among the plays staged in 1959 were two performances of Terlalu gelap diluar (Too dark outside) written by local theatre figure Rachman Arge, who also took the leading role. The second show, in particular, which was presented 'in the round' and described as the first arena-style production in

30 The founding of LEKRA's Makassar branch, on 6 April 1955 is mentioned in the cultural news (Berita Kebudajaan) section of Budaya 4-4/5 (April/May1955):240.

31 Lembaga 1-42 in Harian Marhaen, 27-12-1955.

32 Harian Marhaen, 16-1-1956.

33 Lembaga 2-46, 47 in Harian Marhaen, 24-1-1956 and 31-1-1956.

34 Lembaga 3-18 in Minggu Marhaen, 4-5-1957.

35 The conference was intended to involve theatre practitioners and devotees from whole of Eastern Indonesia. Unfortunately, transport problems prevented representatives from Kalimantan and elsewhere from attending, so that only Sulawesi-based groups were present. Nevertheless the numbers were impressive - 29 groups attended from Makassar alone. See Sulawesi 1-4 (December 1958). 
South Sulawesi (Fahmi Syariff n.d.:55), attracted much interest and critical commentary. ${ }^{36}$ Arge and another, somewhat younger performer-dramatist-director, Aspar Paturusi, were becoming established at this time; both went on to became famous figures on the national theatre scene. A number of arts/literature organizations sponsored theatre productions, amongst their other activities. These included Seniman Kota Besar Makassar (Artists of the City of Makassar), Fron Seniman Makassar (FRONSEMA, Makassar Artists' Front) and Gelora Seni dan Budaya Anak Sekarang (GESAS, The Spirit of Contemporary Youth in Art and Culture).

Meanwhile, according to the accounts of Anis Kaba and his friends, the most active and well-organized arts association during these years was centred in the town of Pare-Pare north of Makassar, with a membership of high school students. In April 1957, the Organisasi Seniman Muda (ORSENIM, Organization of Young Artists) was founded in Pare-Pare among senior high school students and other young people all under twenty years of age. Initially it focused specifically on drama and literature, but soon sections for sculpture, painting, dance, martial arts (pencak silat), singing and music were also added. Salim Said (b. 1943), later to become prominent in culture and politics at the national level, headed the literature section. The initial motto of the group, Seni untuk seni (art for art's sake) attracted criticism for being too 'individualistic'; it was quickly changed to 'We devote our Art to society, because art is a mirror of society' ${ }^{37} \mathrm{~A}$ regular stencilled bulletin was produced, titled simply ORSENIM, containing poems, short stories and essays by members as well as reports of poetry readings and arts events. In March 1959, a branch of ORSENIM was set up in Makassar, at the initiative of Anis Kaba who became secretary of the organization. ${ }^{38}$ Later branches were established also in Gowa, Bone, Barru, Pinrang and Lengga.

My informants explained the dynamism of cultural activities in Pare-Pare in terms of the prosperity of the town as a trading centre, particularly in copra. As the profits from illegal trade in copra, evading central government restrictions, flowed to local government, military and business, the physical environment of the town

\footnotetext{
36 See three articles reviewing and critiquing the play in the cultural supplement Lembaga of Harian Marhaen, Sjafii Atmadja 1959; Harun Hasjid Djibe 1959; and Salman 1959.

37 Kami mengabdikan Seni untuk masjarakat karena seni adalah tjermin masjarakat.

38 Newspaper clippings and handwritten notes from Anis Kaba's collection indicate that he wrote to the central committee of ORSENIM in Pare-Pare in January 1959, on behalf of a group of students at SMP IV Makassar, requesting permission to establish a branch of the organization in Makassar. They received a letter giving them the mandate to do so. Anis Kaba was seventeen at the time; presumably his fellow students were of similar age.
} 
flourished, and the arts benefited. Several government and military figures seem moreover to have been involved in the arts as organizers and instructors. Makassar, by comparison, was just establishing its new, post-independence governmental structure, the Dutch had just left and Darul Islam was causing disturbances. Strikingly, there is no mention, either in the accounts of my informants or in written sources, of the fact that ORSENIM was founded just a month after the declaration of the PERMESTA regional rebellion in March 1957. Although, like others, artists may have sympathized with the political grievances motivating the rebellion, in their creative work and cultural activities there is an unwavering sense of contributing to a single nation. ${ }^{39}$ Perhaps it is for this reason that the social and political upheaval caused by the Darul Islam rebellion and the events and issues of PERMESTA find little explicit mention in their work.

\section{INNOVATION IN TRADITIONAL PERFORMANCE}

While the main focus of this paper is modern Indonesian literature, theatre and popular entertainment, in keeping with the contacts I made in Makassar and the materials collected, one outstanding figure in the field of traditional arts must be mentioned - Andi Nurhani Sapada (1929-2010). I had the good fortune to meet her in 2008 when she was 79, and to hear of her experiences in modernizing and secularizing traditional dance with her innovative choreography. Andi Nurhani Sapada (her childhood name was Andi Nurhani Makkasau, Sapada is from her husband's name) was born of a noble family (reflected in her title 'Andi'), and educated in Dutch schools in Makassar and Ambon, where her grandfather was stationed as a civil servant. Returning to Makassar in 1946, still at the time of the Negara Indonesia Timur, she resumed her education. She recalls that her first contact with Sulawesi dance came about because some Dutch dignitaries were visiting the school and wished to see a 'traditional' dance performance. The wife of one of her teachers was a very good dancer, so she trained a group of six girls to perform, including the young Andi Nurhani Makkasau.

39 At least one important figure in arts and culture in Makassar took an active part in the PERMESTA rebellion. A. Moein, a leading journalist and newspaper editor, who was also prominent in drama, poetry writing and literary discussions, went in 1957 to Menado in North Sulawesi, where the PERMESTA government was centred. As head of the Pemuda PERMESTA Indonesia Timur (PERMESTA Youth of East Indonesia), he remained in Menado for five years, while at times publishing in the Makassar press under an assumed name (A. Moein, personal communication, June 2008). 
In 1950, when President Soekarno visited Sulawesi and asked to see some traditional dance, Andi Nurhani was asked to prepare something, and staged a version of the pattudu, the traditional dance from the Mandar area that she had learnt with her teacher. ${ }^{40}$

The choreography for which Andi Nurhani Sapada is most famous is that of the pakarena, originally a lengthy ritual dance performed in villages and for Makassarese royalty. She reports that with her European education she knew nothing about traditional dance, ${ }^{41}$ but set about learning it from village experts in 1951. A specific motivation was the visit to Sulawesi of a group of performers from Yogyakarta who visited that year to learn local dance and music. She speaks of summoning two musicians, Fachruddin Daeng Romo and Mappaselleng Daeng Maggau, experts in pakarena drumming style, along with a troupe of dancers, and working with them and the group from Yogyakarta for three days straight.

Another stimulus for working with the pakarena was the fact that she was asked each year to present this dance at the Independence Day celebrations in the presidential palace (Istana Negara) in Jakarta. Not many provinces were invited, she suggests, but her pakarena performance, representing the province of Sulawesi, was always included. Fearing that the same dance repeated each year might become monotonous, in 1955-1956 she started making small changes, beginning with the colours of the dancers' costumes. While red had traditionally been used for commoners and green for aristocrats, she started using these colours with no connections to the dancers' status, and introduced other hues as well, for variation and to make an attractive composition. 'Saya main warna', 'I played with colours', she says. Her family were unhappy, asking why she allowed commoners to wear green. For beauty, for aesthetic reasons, she replied, to make performances dynamic rather than static and to prevent the dance form from dying.

During her visit to the palace, Andi Sapada reports, she often talked (in Dutch) with President Soekarno, and received valued advice from him about her dance performances. But she recalls an early occasion where his comments caused her considerable alarm and stress. As mentioned by Jennifer Lindsay in her contribution to this volume, Andi Sapada and a pakarena group representing

40 R. Anderson Sutton (2002:52-3), in his discussion of Andi Sapada's work identifies the dance as the pattudu. In speaking with me about the dance presented at her school and the performance for Soekarno, Andi Sapada didn't mention the name of the dance.

41 She had a keen interest in Western and Western-derived music, however. Sutton (2002:52) reports that she sang with an ensemble and on the radio in Makassar in the late 1940s, using an assumed name since it was inappropriate for a woman of aristocratic family to be an 'entertainer'. 
Sulawesi were included in the Indonesian cultural mission to the People's Republic of China in 1954. Before departure, the performing groups gathered at the presidential palace in Jakarta for final rehearsals. President Soekarno watched, and made comments on certain groups. Asking his view of the pakarena she heard that he considered it kurang kompak, not cohesive enough. 'How could we be kompak?' she asks. As traditional artists they knew nothing about such matters. The drummers followed a particular rhythm, but it had no codified structure; the dancers moved at their own slow pace. Looking at the dance she could see the need to change these elements and make it more interesting for audiences, but how was she to do that, alone in Jakarta with no one to talk to about such issues? What she did was to introduce a new drum beat, to mark the points where the dancers needed to change position. This strategy seems to have pleased or at least amused Soekarno; Andi Sapada reports that he laughed as he watched the second rehearsal. Later she evidently became much bolder in introducing changes to the pakarena form. Her innovations continued and developed over the decades, involving a dramatic shortening of the original length of the dance, and radical changes to its musical accompaniment (Sutton 2002:53-5). Reportedly not everyone was pleased with her innovations; some saw them as undermining the unique identity and artistry of the original form. But today all acknowledge her huge contribution to the development of the performing arts in South Sulawesi. ${ }^{42}$

Andi Sapada spoke proudly of her participation in the Independence Day celebrations, and of her experiences as a member of the cultural mission to China in 1954. The innovative creativity and enthusiastic openness to new influences described by Jennifer Lindsay among members of the cultural missions, and by Irawati Durban Ardjo among West Javanese dancers who participated both in these missions and in Soekarno's Independence Day celebrations, are strongly echoed in Andi Sapada's experience. In addition to her creative activities, she was also active in dance education. With the assistance of her husband, Andi Sapada Mappangile, whom she had married in 1950, Andi Sapada founded a network of dance

42 Sutton observes that the drummers who worked closely with Andi Sapada, namely Fachruddin Daeng Romo and Mappaselleng Daeng Maggau, although not always agreeing with the changes that Andi Sapada and her followers introduced, endorsed the benefit of broadening the appeal of Makasssarese arts. He cites the views of Daeng Romo, who described how the original music of pakarena, involving soulful singing and thunderous drumming, had 'expressed the strong, extroverted ideal of Makassarese masculinity' as contrasted with 'the essence of composure' embodied by the almost motionless female dancers (Sutton 2002:54). In the new version of the pakarena this contrast was no longer emphasized: the role of the musicians was reduced and muted and the dancers were more active and deliberately alluring. 
schools, the Institut Kesenian Sulawesi(Sulawesi Arts Institute) where her creations and approach to dance were taught. Her husband's position as a bupati (district head) ${ }^{43}$ facilitated the founding of IKS branches in the majority of provincial districts, establishing an ongoing model for the practice of Sulawesi dance and its musical accompaniment. Andi Sapada's shortened and streamlined $p a k$ arena, in particular, became the dance form through which South Sulawesi represented itself to the nation and the world.

\section{SOURCES OF ARTISTIC ENERGIES AND IDEALS?}

Although the above account of cultural activities in South Sulawesi in the 1950s is necessarily partial and piecemeal, it reveals a picture of dynamism and energy clearly at odds with the suggestion that difficult political conditions may have dampened interest in cultural concerns. What factors motivated and shaped this lively cultural scene is a question for which I have no definitive answers, but can offer some conjectural thoughts.

One thing that stands out in conversing and reading about cultural activities in Sulawesi in the 1950s is the existence of an ethnically diverse, well-educated elite with a strong sense of artistic and nationalist mission. Some came from aristocratic families; most had either attended Dutch schools themselves or had Dutch-educated parents. Often such individuals were involved in several fields - in journalism and/or politics as well as cultural activities, and skilled in several art forms. The same names recur across time and in different capacities and combinations. These people knew one another, and collaborated together on various kinds of ventures. Some were or later became, nationally-renowned.

A figure mentioned several times above, for example, is J.E. Tatengkeng. Born in North Sulawesi in 1907, Tatengkeng had attended a Dutch primary school, then schools and colleges in Bandung and Solo, and became a well-known poet and member of the Pujangga Baru literary movement. In the late 1940s he held the positions of Minister of Education and Prime Minister of Negara Indonesia Timur ${ }^{44}$ and by 1955 was Head of the Department of Arts

43 Sutton (2002:55) reports that Andi Sapada (Mappangile) was posted in 1960 as bupati (district head) to the district of Sidenreng-Rappang. He does not indicate whether this was his first appointment as bupati.

44 Tatengkeng is mentioned as Minister of Education in March 1949. He held the post of Prime Minister of NIT from 27 December 1949-14 March 1950. http://en.wikipedia.org/wiki/ Jan_Engelbert_Tatengkeng\#Early_Life. 
and Culture, for the province of Sulawesi. ${ }^{45}$ Meanwhile, Tatengkeng continued to write literary works and contribute to cultural debates. In December 1955, for example, he was involved in an exchange about literature, philosophy and morality with the writer Salman A.S in the Lembaga cultural supplement, which also occasionally published his poems. And in September 1958 he launched a new monthly cultural magazine, Sulawesi, Madjallah Kebudajaan, of which he was chief editor, with an editorial board that comprised local writers and artists, and national figures such as Trisno Sumardjo and Gadis Rasjid of Jakarta and Njoman Pandji Tisna of Bali named as assistant editors. Trisno Sumardjo contributed a regular Surat dari Djakarta (Letter from Jakarta), about cultural developments in the capital: Tatengkeng published a short story about his traumatic first days in a Dutch primary school, and a one-act play, Lena, about an independent-minded young woman who leads a workers' strike (Tatengkeng 1958c, 1958b). Outlining the aims of the magazine in his introduction to the first issue, Tatengkeng speaks of providing a medium for creative artists and thinkers to convey their works to the public. The term 'Sulawesi' in the title is explained as a penugasan, the assignment of a task to the artists of Sulawesi to foster this new human life. The intent is not exclusive: in nurturing creative life in Sulawesi, Tatengkeng (1958a) writes, we are also building the world.

Like Tatengkeng, Henk Rondonuwu was another Minahasan whose activities spanned many fields, including politics and the arts, and involved collaboration with a wide range of people. In 1947, Rondonuwu, together with two colleagues, an Ambonese and a Makassarese, co-founded the oldest ongoing newspaper in Makassar, Pedoman Rakjat. At the time of the 1955 drama festival, he appears as one of the organizers, along with Andi Sapada Mappangile, Andi Sapada herself, and J.E. Tatengkeng. Rondonowu (referred to with great warmth as Pak Henky by Pak Anis and his friends) was head of LESFIRA, the film and drama association. They report that he was also a central figure in LASDI, the Indonesian theatre academy, founded in 1959. As head of LESFIRA he was much involved in the making of the organization's first film, Pradjurit tauladan (The model soldier) in 1959, again in collaboration with Andi Sapada Mappangile who was one of the film's co-producers. The film, seen to contain useful educative material about civil-military relations, received strong military support; a high-ranking officer gave technical advice, and four battalions and several individual soldiers participated in the action. ${ }^{46}$

45 Sulawesi was a single province at that time. Separate provinces of North and South Sulawesi were established in September 1960 (Harvey 1977:415).

46 Sulawesi 1-7 (March 1959):308. 
Among local Bugis-Makassarese figures, Andi Sapada and her husband stand out. With their skills and energy, they made much of the opportunities and connections opened up by their aristocratic family backgrounds and Dutch education to develop and promote new cultural forms. While Andi Sapada's activities lay mainly in the field of traditional dance, her husband's interests ranged more broadly, and both were prominent, widely-connected public figures. A different model is provided by Salim Said, growing up in a wealthy business family, taking a leading role in youthful literary activities in his home city, then moving on to Jakarta and the wider international world as a journalist, academic, military analyst, film expert and diplomat. A number of other figures I met experienced less illustrious careers, but nevertheless had been influential in a range of cultural fields. A painter and illustrator, Ali Walgandi, now over eighty and walking with a stick, a frequent visitor to Anis Kaba's house, spoke of his involvement in theatre as well as visual arts. Indeed he is mentioned as the director of the production Terlalu gelap diluar the first play presented in the round in Sulawesi (Fahmi Syariff n.d.:55), and as a contributor to other performances. He organized and exhibited in an art exhibition sponsored by LASDI in May 1959, and he appears on the editorial board of J.E. Tatengkeng's cultural magazine Sulawesi, which published many of his sketches.

A shared motivation for these activities seems to be a sense of duty and a desire to contribute culturally to a new era-J.E. Tatengkeng's talk of assigning tasks to artists, Andi Sapada's wish to revitalize traditional dance for today. There was encouragement and support from official sources, from government and military officials who saw lively cultural activity as both entertaining and edifying local people and signalling to the outside world the stability and progress of their region. Rather than impeding involvement in the building of a new national culture, the establishment of the Negara Indonesia Timur, which built up the importance of Makassar as a regional centre, and brought together people from different regions and backgrounds in its administration, arguably strengthened this role. Artists, writers and performers benefited from targeted facilities and gained enhanced confidence in the importance of their work.

Meanwhile, young people embraced arts activities enthusiastically as great fun. Newspapers of the 1950s contain announcement of malam gembira, literally 'nights of gaiety', evening concerts. Anis Kaba describes how these events were organized. He and his friends would look around for someone with a big yard where they could gather and drink tea; someone might give a lecture and there was always poetry-reading, music and dance. In addition to the exuber- 
ant enjoyment of such evenings, there was an additional sense of bagaimana kita ke depan, 'where are we going, what are we contributing to the future?' When someone read a poem others would comment and criticize, and later the writer would publish the revised, improved version in one of the newspapers. In their enthusiasm to be involved in the arts, to have an outlet for their expression, young writers and activists would join in with whatever was happening; play productions, poetry readings, discussions. It made no difference who was doing the organizing, Anis Kaba reports the Muhammadiyah Muslim organization, the Catholic church, a socialist-leaning newspaper. They published their writing in whichever newspaper would accept it. The newspapers, in turn, selected material on the basis of its content, not the affiliation of the writer.

Anis Kaba's account of youthful artistic activities resonates with my impression outlined above of the fluid involvements and varied collaborations of elite cultural figures. Interactions among participants in the South Sulawesi arts scene were certainly not always harmonious - acrimonious, personally targeted exchanges occur fairly frequently in the cultural segments of the newspapers. What is clear, however, is that certainly during the 1950 s there was a sense of shared involvement in an enterprise with a common ideal and goal, that of creating Indonesian culture.

\section{SOUTH SULAWESI AT THE TIME OF THE GREAT DIVIDE}

Just how much that picture changed in the early 1960s in keeping with political developments and cultural shifts at the national level is something I have found very difficult to determine. Without regular newspaper holdings to consult, ${ }^{47}$ only occasional clippings and some theatre programs, my main source has been the recollections of a small number of informants, shaped by their experiences on one point of the political spectrum. The following are some tentative thoughts, and ideas for further investigation.

Anis Kaba and his friends report on a general heightening of political consciousness and tightening of political affiliations after President Soekarno's Political Manifesto declaration of 1959. All arts and cultural organizations now felt the need for protection by affiliation with a political party, or other body located within the framework of

47 Library holdings of Sulawesi newspapers I've been able to consult in Australia do not go beyond 1960. Monash University library's issues of Harian Marhaen cease in 1959; the National Library of Australia's Sulawesi, Madjallah Kebudajaan holdings date from 1958 to 1960. 
the state ideology of Nasionalisme, Agama, Komunisme (NASAKOM, Nationalism, Religion and Communism). In Makassar as elsewhere, Anis and friends report, the LKN (Lembaga Kebudajaan Nasional, Institute of National Culture) was the PNI-linked cultural organization, LEKRA the communist-linked group, and Lembaga Seniman Budayawan Muslim Indonesia (LESBUMI, Institute of Indonesian Muslim Artists and Cultural Figures) had Nahdlatul Ulama connections. The group Ikatan Seniman Budajawan Muhammadijah (ISBM, Muhammadiyah League of Artists and Cultural Figures), was also prominent. They describe Himpunan Seni Budaja Islam (HSBI, The Association for Islamic Arts and Culture), the modernist Islamic cultural organization discussed by Choirotun Chisaan in her essay in this volume, as present in Makassar but not particularly active. Newspapers too, had clear political connections. Marhaen intensified its links with the Jakarta PNI paper Suluh Marhaen; LKN maintained a weekly paper Expres Minggu; the paper most closely-identified with the Communist Party was Pos Minggu Pagi ${ }^{48}$ while Muhammadiyah was represented in Makassar by the Jakarta-based paper Mertju Suar. It was not until 1964, however, that positions hardened. Up until then, the formation of ad hoc cultural clusters and movement of writers and performers between groups pertained. ${ }^{49}$ With the declaration of the Cultural Manifesto (Manifesto Kebudayaan, later derisively dubbed 'Manikebu') by a number of prominent independent writers in Jakarta in August 1963, its denunciation by the Left, subsequent banning by Soekarno and rejection by government-linked cultural organizations, antagonisms sharpened.

Newspaper reports of the time reflect the mood of confrontation. ${ }^{50}$ An account in the communist-aligned Jakarta daily Harian Rakjat of 26 January 1964 of a meeting held in Makassar on 5 Janu-

48 Although sometimes speaking in terms that might imply that Pos Minggu Pagi was Communist-connected, Pak Anis and his friends explain that the newspaper and its editor were aligned with the leftist Indonesia Party (PARTINDO) rather than directly with the PKI or LEKRA.

49 Theatre programs I obtained for 1959-1960 still indicate both the names of the actors and the independent amateur group or cultural organization presenting the performance. Those from 1963-1964 indicate instead the performers' institutional affiliation - Pemuda Muhammadijah Mamadjang, the LKN-linked weekly Expres Minggu, the student association of the drama academy.

50 Unfortunately I have not had access to accounts in local newspapers of the meeting in Makassar to discuss the Manifesto Kebudayaan. It would have been in keeping with the interests of the Jakarta-based, communist-linked paper Harian Rakjat to report the reception of the Manifesto in the regions as hostile and friction-laden. Nevertheless the reports that I cite from the Makassar press of subsequent developments - conflict over the KKPSI writers' conference, calls by the left-linked Pos Minggu Pagi for the banning of other newspapers, revenge attacks on the offices of Pos Minggu Pagi-clearly indicate strong antagonism in the cultural field between communist-sympathising groups and others. 
ary to discuss the Cultural Manifesto conveys the mounting tension as speakers for and against the Manifesto took the floor. It describes the overwhelming rejection of the document, as only 6 of the 30 people present signed their names, and reports that ridicule and anger were directed at the document's supporters, attributing to them statements such as, "We love the colonialists because they are also human beings. We must be tolerant towards imperialism [... ${ }^{\prime}{ }^{51}$ In the previous Sunday's Harian Rakjat, Rosady Sani, editor of Pos Minggu Pagi, identified here as head of the organization Lembaga Seni Budaja Indonesia (LESBI, Institute for Indonesian Arts and Culture), for South Sulawesi, ${ }^{52}$ attacks the Manifesto and denounces it as the motor for a coming event, the Konferensi Karyawan Pengarang Se Indonesia (KKPSI, All-Indonesia Writers' Conference) in Jakarta. He criticizes the high-handed, biased process of selection of Sulawesi participants in the conference, who are seen as in no way representative of their region.

By contrast, the LKN-connected Makassar weekly Expres Min$g g u$, although in no way supporting the Manifesto Kebudayaan, rejects any suggestion of its connection with the KKPSI writers' conference. ${ }^{53}$ The entire front page of the 22 March 1964 edition of Expres Minggu is devoted to articles concerning the KKPSI conference which took place from 1-7 March, praising its support of Pancasila state ideology and President Soekarno's Political Manifesto, and listing the important writers, government officials and military figures who attended. Those who have labelled the event counter-revolutionary and attempted to undermine it are vehemently denounced, with the names of the Pos Minggu Pagi editors Rosadi Sani and Hasan Usman mentioned explicitly. A satirical column purporting to represent the views of Pos Minggu Pagi gives nonsensical explanations of the term 'counter-revolutionary' and suggests that this category includes all kinds of esteemed institutions and individuals. The paper also reports angry reactions from the public to a call in Pos Minggu Pagi for Expres Minggu and other Makassar newspapers to be shut down. The offices of Pos Minggu Pagi and some other sites in the city had been defaced with graffiti and stones thrown at the home of one of the editors. ${ }^{54}$

51 'Kita tjinta kaum kolonial karena dia djuga manusia. Kita harus toleran kepada imperialisme [...]' (Edi Anribalij 1964).

52 Anis Kaba and friends explain that both the cultural organization LESBI and the newspaper Pos Minggu Pagi, were aligned with the PARTINDO party.

53 In actuality the KKPSI conference was indeed organized by groups associated with the Manifesto Kebudayaan, and received explicit support and logistical assistance from the army (Foulcher 1986:126).

54 Expres Minggu, 22-3-1964. 
Ongoing conflict between Pos Minggu Pagi on one side and LKN and other non-Communist organizations on the other is evident from reports in Expres Minggu in early August 1964. The 2 August edition reports a joint declaration by LKN and LESBUMI, rejecting the holding of a planned Musjawarah Besar Seniman Revolusioner se Kota Besar Makassar (Grand Conference of Makassar Revolutionary Artists) organized by Gelanggang (Arena), the culture segment of Pos Minggu Pagi, headed by A. Rosady Sani. The stated reason for their rejection is that the conference 'does not involve progressive and revolutionary artistic and cultural groups from the NASAKOM alliance'. Statements of rejection by the Muslim-connected cultural organization HSBI and the arts group Tifa are also included. ${ }^{55}$

However, beyond the sharp division separating the anti-communist and communist-identified groups, more flexible interactions still seem to have taken place. The 2 August 1964 edition of Expres Minggu announces the holding of a poetry-reading competition organized by LKN to both celebrate Independence Day and promote a 'crash program' to make South Sulawesi a lumbung pangan, 'food storehouse', or agriculturally wealthy. Participants had to present one of the winning entries from a writing competition that had been held by LKN the preceding June on the occasion of the 37 th anniversary of the PNI. ${ }^{56}$ Interestingly, the winning story in the writing competition, Tanah harapan (Land of hope), was by Mochtar Pabotinggi, and one of the winning poems was Mentari petani (The farmers' sun) by Anis Kaba. ${ }^{57}$ Mochtar Pabotinggi, later to become nationally prominent as a political analyst with the Indo-

\section{Expres Minggu, 2-8-1964.}

56 Harian Tanah Air, 6-6-1964.

57 The agricultural 'crash program' is mentioned as the context of the writing competition, too, as well as the poetry-reading contest. Mochtar Pabotinggi's Tanah harapan is an engaging account of a young woman's return from the city to her home area, now a wasteland after its seizure by savage gerombolan (rebels) in a wave of killing. Although the rebels have now departed, the previous residents do not dare to return, believing the land to be cursed. The young woman tells the old horse cart driver escorting her, an elder in the community, about her meeting in a dream with a beautiful goddess, Dewi Sri, who has promised that the land will prosper if only upright people live there. The old man joyfully states that he will summon back the inhabitants, and the young woman, previously unsure if she is ready for marriage, decides to marry her fiancé and settle there, to raise a family and build up the land. The story of the dream has been a fabrication, designed to allay the superstitious fears of the old man and the other villagers, but the young woman's commitment is real.

Unfortunately I do not have a copy of Anis Kaba's Mentari petani, although another poem he wrote and published in 1964, Lelaki tanah dusun (Man of village land), picturing a farmer faithfully, tirelessly working his land, may indicate something of what it was like. The winning entry in the poetry competition (Anis Kaba was one of the runners up), Mentari ditengah sawah (Sun in the rice-fields) by Malik Jasin BS, consists of repeated exhortations to raise hoes and work together to make South Sulawesi fertile and Indonesia prosperous and free. 
nesian Institute of Social Sciences, LIPI, was very active at that time in Muhammadiyah-linked cultural activities. Anis Kaba likewise was much involved in Muhammadiyah and its arts organization ISBM. Both Pabotinggi and Anis Kabar are mentioned as members of the organizational committee of the Mamadjang branch of Muhammadiyah $;^{58}$ both participated in the production of several ISBM plays. Their success in a competition run by the nationalists may suggest a degree of continuation, even in this polarized period, of the fluid relations between individual writers and cultural organizations described earlier.

In the field of modern theatre during this period, rivalry within Islamic groups, the Muhammadiyah-linked ISBM and NU-aligned LESBUMI, was reportedly a dominant factor (Fahmi Syariff n.d.:3640; Anis Kaba personal communication). LESBUMI's involvement through NU with the government's NASAKOM project, in contrast to ISBM's independent position, was one source of friction. Of major importance was the fact that the two major dramatists and directors, Rachman Arge and Aspar Paturusi, were in different camps; Aspar with ISBM, and Arge in LESBUMI. ${ }^{59}$ A relatively lowlevel of competition from the Left compared to Jakarta and other regions may have contributed to this situation. Anis Kabar and his friends mention that LEKRA was not very active in modern theatre in Makassar, concentrating its energies instead on traditional performances among Javanese migrant communities. Thus in Makassar theatre, friction and competition between Islamic groups was more significant than Left-Right rivalry. As in the case of Bali described by Darma Putra in his contribution to this volume, the divisions that predominated in the local context did not necessarily correspond to the national picture.

Precisely how these differences affected performances and how the rivalry was played out is unclear, merely hinted at rather than discussed directly in available sources. Fahmi Syariff reports how a village presentation by an ISBM group of a play with a strong Islamic proselytizing intent, using Arabic dress and sound effects of camels, was plunged into darkness when four unknown individuals ran off with the lamps illuminating the stage. He suggests that the incident shows how seriously conflicts between political organizations impacted on Islamic arts at the village level. But regard-

58 Mertju Suar, 3-3-1965.

59 The Harian Rakjat report of the Makassar meeting concerning the Manifesto Kebudayaan gives a picture of the differing positions of the two figures. Aspar is described speaking fierily in support of the document, being talked down by the meeting, but stating that he will nevertheless sign it as an individual. Arge asserted that unless the Manifesto had been produced by a gathering of NASAKOM artists, there was nothing to discuss, he was against it (Edi Anribalij 1964). 
ing the cause of the disruption he says only that the owners of the lamps were not from Muhammadiyah circles. Whether rival LESBUMI groups were suspected as perpetrators, whether rejection of the overtly proselytizing style or Middle Eastern imagery of the play played any part in the incident is not explained (Fahmi Syariff n.d.:37-8).

Another example of the challenges facing theatre productions in this context, apart from the ISBM-LESBUMI conflict, is the 1964 ISBM production Jang konsekwen (The principled one), directed by Aspar, with Anis Kaba as head of production. The initial plan to stage Domba-domba Revolusi (Lambs of the Revolution) by Javanese playwright B. Soelarto, foundered when the play was deemed counter-revolutionary and the police denied a performance permit. The performers then changed the title of the play, while retaining its theme, that of an honest hero - here clearly defined as a devout Muslim - who resists the temptations offered him to join corrupt intrigues among government and military figures. The next hurdle was the ruling by the Muhammadiyah that male and female actors could not appear on stage together, whereas the play contained a number of important female roles. Fortunately, the performers were able to appeal to the Islamic writer and intellectual Hamka, ${ }^{60}$ who happened to be in Makassar at the time. With Hamka's blessing the play was able to go ahead with a mixed male and female cast. On the night of the performance, however, LEKRA staged a noisy event outside the theatre, intended to disrupt proceedings. While LEKRA staged few plays of their own, the use of spoiling tactics was fairly common. ${ }^{61}$

Rahman Arge himself plays down the notion of conflict among Islamic cultural organizations and theatre groups in the pre-1965 years. Instead he highlights a production which he describes as bringing together the different groups, not only ISBM and LESBUMI but also LKN, in shared artistic and ideological expression. Around 1963-1964 Arge wrote a play Tanah dan hati manusia (Land and the human heart) on the theme of conflict over land. He suggests that it proposed a 'humanistic' solution to land disputes, though discussion and negotiation, in contrast to the class conflict promoted by the communists. ${ }^{6}$

The play takes place in a village setting: a student from an aristocratic landowning family has returned to assist local farmers achieve

60 For a discussion of Hamka's importance as a religious and cultural figure in this period see Hairus Salim's contribution to this volume.

61 Anis Kabar, personal communication, June 2009.

62 Personal communication by phone, 23-10-2009. 
better conditions, not by physically attacking the wealthy landowners who are exploiting them but by using the structures of the state to achieve their rights. The student, Bachtiar, also enlightens the farmers about the injustices of the aristocratic class system, at odds with the ideal of social equality central to both Islamic religion and modern progress. In the final scene Bachtiar and a farmer friend confront Bachtiar's uncle, the evil local landlord, and his henchmen. When conflict escalates and the uncle calls for the police, Bachtiar reveals that he has already contacted the police, as well as security guards and legal officials. He has informed them of the uncle's offences, including not only exploiting farmers but also protecting gangs of gerombolan (Darul Islam rebels), and collaborating with the communist organization for farmers, (Barisan Tani Indonesia, BTI) in destroying rival traders. Now the farmers will see how the institutions of the state protect their interests. ${ }^{63}$

Arge reports that the play was staged for a large gathering at the Senayan stadium in Jakarta in August 1965, involving performance groups from all over Indonesia. He was the director, and Aspar Paturusi one of the actors. While the performances were supposed to address socialist themes, their play celebrated 'humanistic' values. Fahmi Syariff gives the name of the event where the play was performed as Musyawarah Besar Tani, the 'Grand Congress of Farmers' (Fahmi Syariff n.d.:55). Jakarta newspaper reports from late July and early August 1965 confirm that a Musjawarah Besar Tani Se-Indonesia 'All-Indonesia Grand Congress of Farmers' was held in the city from 20-30 July 1965. They mention at least one evening of theatre performances being staged in conjunction with the congress, although no direct reference is made to a play from South Sulawesi. ${ }^{64}$

If the Tanah dan hati manusia production served to unite Islamic cultural groups, an incident that occurred some years later suggests that tensions and rivalries were not forgotten. A theatre event was held in 1967, intended, Arge reports, to celebrate the joint struggle of the artists of Makassar against the Communists. The groups LESBUMI and ISBM performed on the first two nights, with two individual productions on the third night. The title of the LESBUMI play, Pembentji matahari (literally 'hater of the sun') written and

63 I obtained a copy of the play through Anis Kaba. It appears to have been retyped from the original - it uses the revised spelling system introduced in 1973 and is dated ' 84 ', presumably 1984. Pak Anis suggests that the play was probably retyped in preparation for production by another theatre group at that time.

64 Harian Rakjat, 21-7-1965; Kohar 1965; Soesilo 1965. Fahmi Syariff's account actually cites August 1963 as the date of the Jakarta farmers' congress where Rahman Arge's play was performed. But since newspaper reports of the 1965 Musjawarah Besar Tani describe it as the first event of its kind, 1965 seems clearly the correct date. 
directed by Rahman Arge, was interpreted by some ISBM members as a deliberate assault on the Muhammadiyah, which has the sun as its symbol. In response, Aspar Paturusi wrote a play to be performed by ISBM entitled Membakar dunia (Burn the world) targeting the NU symbol of the globe. In actuality Pembentji matahari is unconnected with Muhammadiyah. The 'hater of the sun' is an outlaw gunrunner, Djoni, who hides away from the light, literally and figuratively, but still has faith in God and rejects the materialist views of his communist companion, Marno. At the point of death, mortally wounded by Marno, yet managing to kill him and save the life of his childhood friend Amal, Djoni asks Amal to remove his sunglasses, gasping 'Aku rindu matahari', 'I miss the sun'. The theme of the play is Djoni's religious redemption, and the symbolic elimination of communism through the death of Marno. Fortunately, the suspicious ISBM members found this out before the theatre event, changed their performance plans, and the play Pembakar dunia was never staged. After its Makassar production Pembentji matahari was presented again at a national theatre festival in Jakarta in 1971 (Fahmi Syariff n.d.:35-6; Anis Kaba and Fahmi Syariff, personal communication).

\section{GONCLUDING THOUGHTS}

The play Pembentji matahari, and the performances of the Islamicaligned theatre groups prior to 1965, illustrate a significant feature of cultural activity in Makassar in the 1950s and 1960s - its participation in national political developments and cultural production, yet local distinctiveness. Cultural life in South Sulawesi in the mid-1960s was politicized through the same cultural streams and organizations as other centres, but local factors shaped the nature of inter-group relations. In modern theatre, Islamic groups which in other areas collaborated to confront a common enemy here sparred with one another. Rivalry among these groups evidently lingered on into the New Order period, even after the time of direct political and cultural conflict had ended. It seems possible that this shared local character, although fraught with its own conflicts, helped facilitate a rebuilding of cultural structures after 1965-1966. In 1968, about thirty artists from the remaining groups held a meeting chaired by Anis Kaba in which it was decided to form a joint cultural body. In July 1969, just six months after the formation of the Dewan Kesenian Jakarta (Jakarta Arts Council), the Dewan Kesenian Makassar (Makassar Arts Council) was established (Fahmi Syariff n.d.:40-1). 
Local distinctiveness did not necessarily involve a local focus. As emphasized above, writers and artists in South Sulawesi in the 1950s and 1960s identified strongly with the Indonesian nation; they saw their work as contributing to the building of a new national culture, rather than focusing more narrowly on regional, local genres and practices. Modern culture for the new nation drew on international models, celebrating liberal, individual values and employing naturalist, realist styles. While contemporary art and performance in South Sulawesi at a later period was to engage creatively with traditional legends and local rituals and performance genres, at this time the emphasis was on the new, the gaze outward. The cultivation of local, traditional cultural forms, in the case of Andi Sapada's work with Sulawesi dance, involved reworking the local to accord with new aesthetic standards and wider public tastes.

In building the new, these writers, artists and cultural figures were fuelled by great enthusiasm and an impressive idealism. They worked across a range of fields, and for much of the period collaborated in varied and productive ways. Responding as creatively as they could to the conditions and opportunities of their time, they leave an important legacy.

REFERENCES

Edi Anribalij

1964 'Kaum, "Manifes” mau revisi Manipol', Harian Rakjat, (26 January).

Fahmi Syariff

n.d.

'Ekologi teater di Sulawesi Selatan', in: Ridwan Effendy and Abd Rojak (eds), Perkembangan kesenian di Sulawesi Selatan.

Foulcher, Keith 1986

Social commitment in literature and the arts; The Indonesian 'Institute of People's Culture' 1950-1965. Clayton: Southeast Asian Studies, Monash University. [Monash papers on Southeast Asia 15.]

Harun Hasjid Djibe

1959 'Lampu sorot didaerah "terlalu gelap diluar”, Lembaga 5-76 in Harian Marhaen, (24 July).

Harvey, Barbara S.

1977 Permesta; Half a rebellion. Ithaca, N.Y.: Cornell Modern Indonesia Project, Southeast Asia Program, Cornell University. 
Jajasan

1949

Jajasan Pusat Kebudajaan Indonesia Timur. Ende, Flores: Arnoldus.

Kohar

1965

'Pameran Mubes Tani', Harian Rakjat Minggu, (1 August).

Nurwahidah

2004

Hj. Andi Siti Nurhani Sapada; Dari sangkar Saoraja menuju pentas dunia. Yogyakarta: Bio Pustaka.

Salman, A.S.

1959

'Permasalahan seniman-seniman KBM', Lembaga 5-79 in Harian Marhaen, (21 August).

Sjafii Atmadja

1959 'Terlalu gelap diluar', Lembaga 5-73 in Harian Marhaen, (3 July).

Sjarief Saleh

1949

'Keharusan-keharusan dalam cipta seni', Pandji Negara 3-22:16.

Soesilo

1965

“"Pengadilan Tani” di tengah-tengah kaum tani Tjengkareng', Harian Rakjat Minggu, (1 August).

Sutton, Richard Anderson

2002

Calling back the spirit; Music, dance, and cultural politics in lowland South Sulawesi. New York: Oxford University Press.

Tatengkeng, J.E.

1958a 'Pengantar', Sulawesi 1-1 (September):1.

1958b 'Lena', Sulawesi 1-1 (September):27-44.

1958c 'Saja masuk sekolah Belanda’, Sulawesi 1-2 (October):63-8. 